\title{
Effect of a Diet Enriched in Whole Linseed and Sunflower Oil on Goat Milk Fatty Acid Composition and Conjugated Linoleic Acid Isomer Profile
}

\author{
P. Luna, ${ }^{*}$ A. Bach, $† \ddagger$ M. Juárez, ${ }^{*}$ and M. A. de la Fuente ${ }^{\star 1}$ \\ *Instituto del Frío (CSIC), José Antonio Novais 10, Ciudad Universitaria, s/n 28040 Madrid, Spain \\ †ICREA (Institució Catalana de Recerca i Estudis Avançats), 08010 Barcelona, Spain \\ $\ddagger$ Grup de Recerca en Nutrició, Maneig i Benestar Animal, Unitat de Remugants, IRTA (Institut de Recerca i Tecnologia Agroalimentàries), \\ 08193 Bellaterra, Spain
}

\section{ABSTRACT}

The aim of the present research was to study changes in milk composition and fatty acid profile, specifically conjugated linoleic acid (CLA) and its isomers, in goat milk as affected by dietary supplementation of sunflower oil and whole linseed (0.81 and $1.84 \%$ of dry matter on basal diet, respectively) and to assess the persistency of the response. To achieve this objective, bulk milk from a herd and from 6 individual dairy goats fed a diet supplemented with sunflower oil and whole linseed was monitored for a period of $3 \mathrm{mo}$. Gas chromatography and silver ion HPLC were used to analyze total CLA content and the isomeric profile of these fatty acids, respectively. The contents of $\alpha$-linolenic acid increased from $0.35 \%$ with the reference diet to $0.62 \%$ with the supplemented diet. Similarly, CLA milk content increased from 0.46 to $1.18 \%$. The same pattern was also observed for trans-11 C18:1 (1.38 to $4.05 \%$, respectively) in goat milk after 3 mo of lipid supplementation. In contrast, changes in other trans C18:1 isomers were less remarkable. There was a strong linear correlation between cis-9, trans-11 C18:2, the main CLA isomer, and trans-11 C18:1 under the conditions assayed and their concentration remained stable throughout the duration of the study. Levels of the minor CLA isomers were also enhanced as a consequence of lipid supplementation. The most remarkable increases were observed for 11-13 (trans-trans and trans-cis geometric isomers), whereas trans-7, cis-9 (the second most important CLA isomer from a quantitative point of view) and trans-10, cis-12 increased only slightly with lipid supplementation.

Key words: goat milk, conjugated linoleic acid, rumenic acid, $\alpha$-linolenic acid

Received June 14, 2007.

Accepted September 14, 2007.

${ }^{1}$ Corresponding author: mafL@if.csic.es

\section{INTRODUCTION}

Goat milk has been identified as an alternative for consumers who are either sensitive or allergic to cow's milk. Lipid composition is one of the most important components of the nutritional quality of goat milk. The nutritional advantage of goat milk fat compared with cow's milk has been attributed to the high content of C6:0 to C10:0 fatty acids, lack of agglutinin, a high percentage of the short- and medium-chain fatty acids esterified on the carbon 3 of the glycerol skeleton, and to a small size of fat globules; hence making the dairy product easily digestible (Chilliard et al., 2006).

Different fatty acids are potentially involved as positive or negative predisposing factors for human health. Rumenic acid (RA, cis-9, trans-11 C18:2), the main natural isomer of conjugated linoleic acid (CLA) seems to act positively on the prevention of some forms of cancer (Lee et al., 2005). The content of RA in goat milk fat can vary widely (Chilliard and Ferlay, 2004; Chilliard et al., 2006) and the underlying factors resulting in this variation are related predominantly to differences in the production systems applied (Mir et al., 1999; Kitessa et al., 2001; Sanz-Sampelayo et al., 2004). Chilliard et al. (2003) reviewed studies involving effects of lipid supplements on milk fat synthesis and concluded that there were many similarities among ruminants, but often goats responded differently than cows. Several other minor CLA isomers generated in the rumen or in the ruminant mammary gland could also be found in goat milk fat but few data are published on the influence of feeding on these minor compounds.

Modifications in milk fatty acids composition through nutrition may result in positive or adverse changes in the flavor and nutritional properties of dairy products from goats. The characteristic flavor of goat cheese, for instance, is particularly affected by the content of shortand medium-chain fatty acid (C6 to C10). Increasing the content of potentially healthy fatty acids in goat milk by dietary manipulation may increase its value. 
Table 1. Ingredient and nutrient composition of the experimental rations

\begin{tabular}{|c|c|c|}
\hline \multirow[b]{2}{*}{ Ingredient (\% of DM) } & \multicolumn{2}{|c|}{ Ration } \\
\hline & Reference & Enriched \\
\hline Alfalfa hay & 16.90 & 13.79 \\
\hline Oats hay & 17.44 & 14.23 \\
\hline Barley straw & 14.85 & 12.12 \\
\hline Beet pulp & 7.50 & 6.12 \\
\hline Oats grain & 4.37 & 3.56 \\
\hline Barley grain & 5.70 & 10.04 \\
\hline Palm oil & 1.06 & 0.87 \\
\hline Corn grain & 7.49 & 6.11 \\
\hline Soybean meal & 16.30 & 13.30 \\
\hline Wheat middlings & 2.01 & 1.64 \\
\hline Wheat grain & 1.71 & 1.39 \\
\hline Distillers dried grains & 1.73 & 5.06 \\
\hline Sunflower meal & 1.25 & 1.02 \\
\hline Canola meal & 0.53 & 0.44 \\
\hline Sepiolite & 0.38 & 0.31 \\
\hline Calcium carbonate & 0.51 & 0.52 \\
\hline Molasses & 0.14 & 0.11 \\
\hline Magnesium oxide & 0.02 & 0.02 \\
\hline Sodium chloride & 0.10 & 0.11 \\
\hline Monocalcic phosphate & 0.04 & 0.03 \\
\hline Corn gluten feed & - & 3.60 \\
\hline Peas & - & 2.90 \\
\hline Whole linseed & - & 1.85 \\
\hline Sunflower oil & - & 0.81 \\
\hline \multicolumn{3}{|l|}{ Nutrients } \\
\hline $\mathrm{CP}$ & 18.5 & 18.8 \\
\hline NDF & 36.4 & 34.3 \\
\hline NFC & 35.8 & 34.3 \\
\hline Ether extract & 3.62 & 5.1 \\
\hline ME (Mcal/kg) & 2.81 & 2.98 \\
\hline Palmitic acid & 1.84 & 1.72 \\
\hline Linoleic acid & 0.51 & 1.11 \\
\hline$\alpha$-Linolenic acid & 0.09 & 0.38 \\
\hline
\end{tabular}

Concentrations of specific health-promoting fatty acids, such $\alpha$-linolenic acid and RA have been increased in cows milk fat by feeding oilseeds rich in C18:3 and C18:2, respectively. However, the maintenance of these changes over time has been questioned by some authors (Chilliard and Ferlay, 2004).

The main objective of this research was to produce CLA-enriched goat milk together with increased levels of $\alpha$-linolenic acid by feeding a diet supplemented with linseed and sunflower oil without impairing animal performance. Special focus was devoted to the evolution CLA isomer profile throughout a 3-mo period.

\section{MATERIALS AND METHODS}

\section{Animals and Dietary Treatments}

Six multiparous lactating dairy Murciano-Granadina goats (DIM $=32 \pm 18 \mathrm{~d}$ ) were used in this study. Animals were handled following the guidelines of the IRTA (Institut de Recerca i Tecnologia Agroalimentàries) Animal Care Committee. At the beginning of the study goats received a typical lactating ration (Table 1) with a forage:concentrate ratio of 40:60 (reference diet). After a month consuming this ration, animals were switched to a similar ration but supplemented with sunflower oil and whole linseed $(0.81$ and $1.84 \% \mathrm{DM}$, respectively) for a period of 3 mo (from April to July). The ingredient composition of this ration changed slightly from the reference diet to maintain $\mathrm{CP}$ and $\mathrm{NDF}$ at levels as close as possible to the reference diet while increasing the fat content and the fatty acid profile of the diet. Milk samples were collected at 0,15 , 30,60 , and $90 \mathrm{~d}$.

\section{Analytical Methods}

Fat, protein, lactose, and TS in milk were measured with a MilkoScan FT-6000 (Foss Electric, Barcelona, Spain). Fatty acids of the dietary components were separated and quantified following AOAC (1990) methods. The extracted fat was mixed with $1 \mathrm{~mL}$ of $1 M \mathrm{KOH}$ and $1 \mathrm{~mL}$ of $14 \% \mathrm{BF}_{3}$ in methanol. The sample was methylated by incubation at $100^{\circ} \mathrm{C}$ for $60 \mathrm{~min}$ and, after cooling to room temperature, was extracted with $5 \mathrm{~mL}$ of hexane. The fatty acid methyl esters (FAME) in the hexane layer were analyzed by GC (5890 Series II GC, Hewlett Packard, S.A., Barcelona, Spain). All samples were methylated in duplicate and introduced into a fused-silica capillary column $(30 \mathrm{~m} \times$ i.d. $0.25 \mathrm{~mm}$, BPX 70, SGE, Austin, TX). Helium was the carrier gas. Column temperature was initially $150^{\circ} \mathrm{C}$ for $1 \mathrm{~min}$, increased by $4^{\circ} \mathrm{C} / \mathrm{min}$ to $200^{\circ} \mathrm{C}$, and was then held at $200^{\circ} \mathrm{C}$ for $10 \mathrm{~min}$.

Milk fat was extracted following the method of Luna et al. (2005a), and FAME were prepared by base-catalyzed methanolysis of the glycerides ( $\mathrm{KOH}$ in methanol) according to an ISO-IDF procedure (2002). Analysis of FAME was performed on a GLC (Agilent 6890 N Network System, Palo Alto, CA) with auto injector, fitted with a flame-ionization detector. The FAME profile was determined by split injection (1:100) onto a CP-Sil 88 fused-silica capillary column $(100 \mathrm{~m} \times 0.25 \mathrm{~mm}$, Varian, Middelburg, the Netherlands) using a programmed temperature gradient method. Helium was the carrier gas and the injector and detector were at $250^{\circ} \mathrm{C}$. Initial oven temperature was $160^{\circ} \mathrm{C}$. After $80 \mathrm{~min}$, oven temperature was then increased at $10^{\circ} \mathrm{C} / \mathrm{min}$ to $210^{\circ} \mathrm{C}$ and held for $35 \mathrm{~min}$.

A butter oil reference standard (CRM 164; European Community Bureau of Reference, Brussels, Belgium) was used to determine the response factors of the individual fatty acids. To identify different isomers, a mixture (cis-9, trans-11; trans-8, cis-10; cis-11, trans-13; trans-10, cis-12 C18:2, and small amounts of a variety of all cis and trans C18:2 isomers) and pure (cis-9, trans11 and trans-10, cis-12 C18:2) CLA methyl esters were 
LUNA ET AL.

Table 2. Effects of dietary supplementation of whole linseed (1.85\% in DM) and sunflower oil $(0.81 \%$ in $\mathrm{DM})$ on milk yield and milk composition of dairy goats ${ }^{1}$

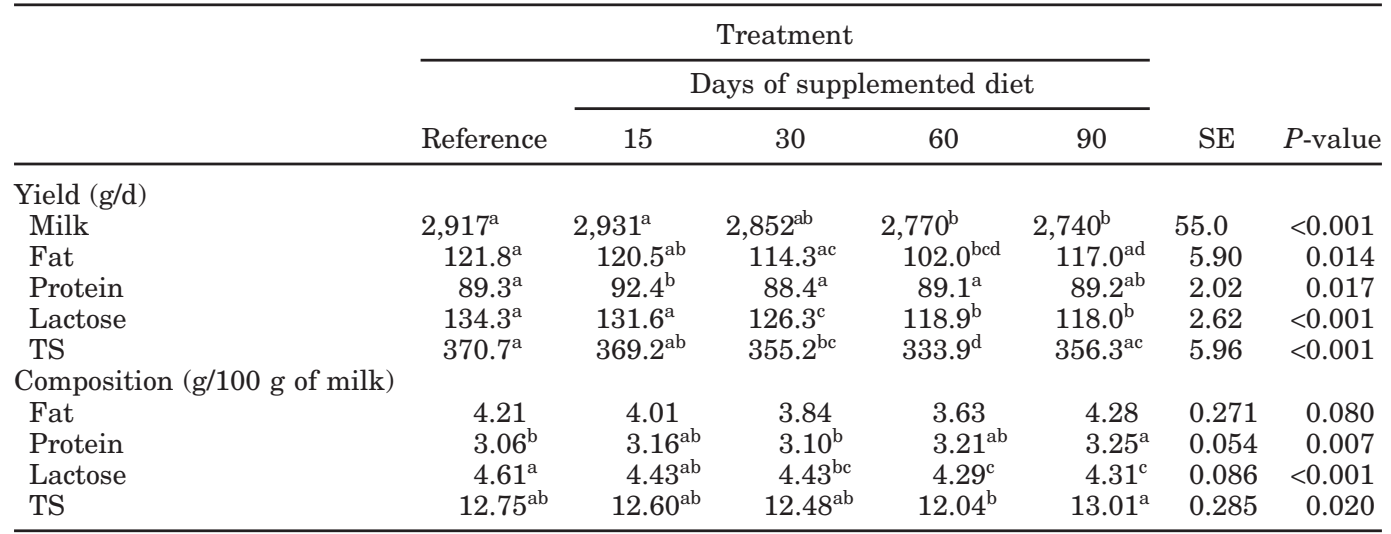

${ }^{\mathrm{a}-\mathrm{d}}$ Means within a row with different superscripts differ $(P<0.05)$.

${ }^{1}$ Data correspond to the analysis of milk from 6 individual goats collected at 0 (reference diet) 15, 30, 60, and $90 \mathrm{~d}$.

purchased from Nu-Chek Prep Inc. (Elysian, MN). To form other CLA isomers, Nu-Chek mixtures were isomerized using $\mathrm{I}_{2}$ following the method described by Eulitz et al. (1999).

Silver-ion HPLC $\left(\mathrm{Ag}^{+}\right.$-HPLC) separation of CLA methyl esters was conducted using an HPLC apparatus (model SPE-MA10AVP, Shimadzu Kyoto, Japan) equipped with a diode array detector operated at 233 $\mathrm{nm}$ at $29^{\circ} \mathrm{C}$. Three ChromSpher 5 Lipids analytical silver-impregnated columns $(250 \mathrm{~mm} \times 4.6 \mathrm{~mm}$ i.d. stainless steel; $5 \mu \mathrm{m}$ particle size; Varian) were used in series. The mobile phase was $0.1 \%$ acetonitrile in hexane and operated isocratically at a flow rate of $1.0 \mathrm{~mL} / \mathrm{min}$. The flow was initiated $0.5 \mathrm{~h}$ before sample injection, and injection volume was $10 \mu \mathrm{L}$. The identification of CLA isomers was based on coinjection with commercial reference material as well as a comparison of the elution order of CLA with existing literature. The chromatographic areas for 7-9, 8-10, and 9-11 were added and used for comparison with the peak area of the 3 isomers from the GC chromatogram. The amounts of the other CLA isomers were calculated from their $\mathrm{Ag}^{+}$-HPLC areas relative to the area of the main isomer, 9-11. The results were expressed as absolute values in milligrams per gram of fat.

\section{Statistical Analysis}

The data from individual goats were analyzed following an ANOVA using a mixed-effects model that accounted for the random effect of goat and the fixed effects time. Time entered the model as a repeated measure following an autoregressive order 1 variance-covariance structure. The variable time was a categorial variable with value of zero when goats received the reference ration, and values of $1,2,4$, and 6 at 15,30 , 60 , and $90 \mathrm{~d}$, respectively, following the change of diet and the introduction of the lipid supplementation. Mean comparisons were conducted using the Scheffé adjustment. The data from bulk tank were analyzed similarly, but excluding the random effect of goat. All statistical analyses were conducted with SAS (SAS Inst. Inc., Cary, NC).

\section{RESULTS AND DISCUSSION}

\section{Animal Performance}

Milk production and composition for the 3-mo duration of the study are reported in Table 2. Milk yield was not affected during the first month of supplementation but a slight decline in milk production (approximately 6 to $7 \%$ ) was recorded at 60 and $90 \mathrm{~d}$. This was most likely because of the effect of lactation progression and not due to the change in dietary treatments. However, fat, protein, and TS contents were not altered. Chilliard et al. (2003, 2006) underlined the fact that, unlike the situation in dairy cows, there is no decrease in milk fat content when the diets supplemented with polyunsaturated fatty acids (PUFA) are fed to dairy goats. Chilliard and Ferlay (2004) suggested that the powerful inhibition of acetyl-CoA carboxylase and de novo lipogenesis elicited by long-chain fatty acid (especially with a high level of unsaturation) seems less strong in the goat mammary gland. Therefore, potential inhibitors of lipogenesis present in the rations would be less active in goats than in dairy cows. In regard to milk protein, it has been observed that the addition of 
Table 3. Effects of dietary supplementation of whole linseed (1.85\% in DM) and sunflower oil (0.81\% in $\mathrm{DM})$ on the fatty acid ( $\mathrm{g} / 100 \mathrm{~g}$ of total fatty acid methyl esters) profile of goat milk ${ }^{1}$

\begin{tabular}{|c|c|c|c|c|c|c|c|}
\hline \multirow[b]{3}{*}{ Fatty acid } & \multicolumn{5}{|c|}{ Treatment } & \multirow[b]{3}{*}{$\mathrm{SE}$} & \multirow[b]{3}{*}{$P$-value } \\
\hline & \multirow[b]{2}{*}{ Reference } & \multicolumn{4}{|c|}{ Days of supplemented diet } & & \\
\hline & & 15 & 30 & 60 & 90 & & \\
\hline $\mathrm{C} 4: 0$ & $3.01^{\mathrm{b}}$ & $3.26^{\mathrm{a}}$ & $3.07^{\mathrm{ab}}$ & $3.09^{\mathrm{ab}}$ & $2.99^{\mathrm{b}}$ & 0.056 & 0.012 \\
\hline C6:0 & $3.25^{\mathrm{b}}$ & $3.61^{\mathrm{a}}$ & $3.29^{\mathrm{b}}$ & $3.30^{\mathrm{b}}$ & $3.15^{\mathrm{b}}$ & 0.085 & 0.003 \\
\hline C8:0 & 3.47 & 3.94 & 3.47 & 3.51 & 3.33 & 0.140 & 0.095 \\
\hline C10:0 & 11.53 & 12.13 & 11.41 & 11.27 & 10.95 & 0.422 & 0.140 \\
\hline C10:1 & 0.28 & 0.26 & 0.24 & 0.25 & 0.23 & 0.021 & 0.265 \\
\hline C12:0 & 4.32 & 4.14 & 4.08 & 4.06 & 3.68 & 0.293 & 0.340 \\
\hline C13:0 & 0.18 & 0.17 & 0.17 & 0.17 & 0.16 & 0.621 & 0.434 \\
\hline $\mathrm{C} 14: 0$ iso & $0.07^{\mathrm{ab}}$ & $0.06^{\mathrm{b}}$ & $0.08^{\mathrm{a}}$ & $0.07^{\mathrm{ab}}$ & $0.06^{\mathrm{b}}$ & 0.007 & 0.012 \\
\hline C14:0 & $8.48^{\mathrm{a}}$ & $7.77^{\mathrm{b}}$ & $8.16^{\mathrm{ab}}$ & $7.89^{\mathrm{b}}$ & $7.93^{\mathrm{b}}$ & 0.218 & $<0.001$ \\
\hline $\mathrm{C} 15: 0$ iso & $0.18^{\mathrm{a}}$ & $0.13^{\mathrm{b}}$ & $0.14^{\mathrm{ab}}$ & $0.13^{\mathrm{ab}}$ & $0.15^{\mathrm{ab}}$ & 0.007 & 0.014 \\
\hline $\mathrm{C} 15: 0$ anteiso & $0.26^{\mathrm{ab}}$ & $0.22^{\mathrm{b}}$ & $0.26^{\mathrm{ab}}$ & $0.25^{\mathrm{b}}$ & $0.23^{\mathrm{b}}$ & 0.016 & 0.001 \\
\hline C14:1 & 0.07 & 0.06 & 0.06 & 0.05 & 0.06 & 0.006 & 0.245 \\
\hline C15:0 & 0.79 & 0.71 & 0.83 & 0.83 & 0.74 & 0.055 & 0.067 \\
\hline $\mathrm{C} 16: 0$ iso & $0.28^{\mathrm{ab}}$ & $0.24^{\mathrm{ab}}$ & $0.30^{\mathrm{a}}$ & $0.30^{\mathrm{ab}}$ & $0.24^{\mathrm{b}}$ & 0.020 & 0.013 \\
\hline C16:0 & $28.40^{\mathrm{a}}$ & $25.91^{\mathrm{b}}$ & $28.11^{\mathrm{a}}$ & $26.38^{\mathrm{b}}$ & $27.14^{\mathrm{ab}}$ & 0.429 & $<0.001$ \\
\hline $\mathrm{C} 17: 0$ iso + trans-9 C16:1 & $0.40^{\mathrm{c}}$ & $0.62^{\mathrm{b}}$ & $0.56^{\mathrm{ab}}$ & $0.69^{\mathrm{ab}}$ & $0.70^{\mathrm{a}}$ & 0.118 & $<0.001$ \\
\hline Cis-7 C16:1 & 0.20 & 0.21 & 0.21 & 0.22 & 0.22 & 0.018 & 0.733 \\
\hline Cis-9 C16:1 + C17:0 anteiso & $0.83^{\mathrm{a}}$ & $0.66^{\mathrm{b}}$ & $0.77^{\mathrm{ab}}$ & $0.68^{\mathrm{ab}}$ & $0.70^{\mathrm{ab}}$ & 0.042 & 0.015 \\
\hline $\mathrm{C} 17: 0$ & 0.58 & 0.52 & 0.58 & 0.57 & 0.53 & 0.038 & 0.058 \\
\hline C17:1 & $0.09^{\mathrm{a}}$ & $0.08^{\mathrm{ab}}$ & $0.07^{\mathrm{ab}}$ & $0.07^{b}$ & $0.07^{\mathrm{ab}}$ & 0.007 & 0.029 \\
\hline C18:0 & 11.46 & 11.03 & 10.47 & 10.84 & 10.25 & 0.734 & 0.780 \\
\hline Trans $6+7+8$ C18:1 & $0.30^{\mathrm{b}}$ & $0.40^{\mathrm{a}}$ & $0.37^{\mathrm{a}}$ & $0.40^{\mathrm{a}}$ & $0.39^{\mathrm{a}}$ & 0.010 & $<0.001$ \\
\hline Trans-9 C18:1 & $0.28^{\mathrm{b}}$ & $0.37^{\mathrm{a}}$ & $0.34^{\mathrm{a}}$ & $0.36^{\mathrm{a}}$ & $0.37^{\mathrm{a}}$ & 0.010 & $<0.001$ \\
\hline Trans-10 C18:1 & $0.41^{\mathrm{b}}$ & $0.65^{\mathrm{a}}$ & $0.57^{\mathrm{a}}$ & $0.66^{\mathrm{a}}$ & $0.54^{\mathrm{ab}}$ & 0.034 & $<0.001$ \\
\hline Trans-11 C18:1 & $1.38^{\mathrm{b}}$ & $3.59^{\mathrm{a}}$ & $3.65^{\mathrm{a}}$ & $3.68^{\mathrm{a}}$ & $4.05^{\mathrm{a}}$ & 0.653 & $<0.001$ \\
\hline Trans-12 C18:1 & $0.50^{\mathrm{b}}$ & $0.64^{\mathrm{a}}$ & $0.59^{\mathrm{ab}}$ & $0.63^{\mathrm{a}}$ & $0.57^{\mathrm{ab}}$ & 0.031 & 0.004 \\
\hline Cis-9 C18:1 & $13.07^{\mathrm{a}}$ & $11.43^{\mathrm{ab}}$ & $11.31^{\mathrm{b}}$ & $11.72^{\mathrm{ab}}$ & $11.77^{\mathrm{ab}}$ & 0.747 & 0.041 \\
\hline Trans-15 +cis-11 C18:1 & $0.47^{\mathrm{b}}$ & $0.55^{\mathrm{a}}$ & $0.52^{\mathrm{ab}}$ & $0.55^{\mathrm{a}}$ & $0.50^{\mathrm{ab}}$ & 0.020 & 0.013 \\
\hline Cis-12 C18:1 & $0.36^{\mathrm{c}}$ & $0.64^{\mathrm{ab}}$ & $0.54^{\mathrm{b}}$ & $0.69^{\mathrm{a}}$ & $0.54^{\mathrm{b}}$ & 0.065 & $<0.001$ \\
\hline Cis-13 C18:1 & $0.05^{\mathrm{c}}$ & $0.07^{\mathrm{a}}$ & $0.06^{\mathrm{ab}}$ & $0.07^{\mathrm{a}}$ & $0.06^{\mathrm{bc}}$ & 0.006 & 0.019 \\
\hline Trans-16 +cis-14 C18:1 & 0.43 & 0.48 & 0.46 & 0.48 & 0.44 & 0.026 & 0.606 \\
\hline Trans-trans C18:2 & $0.09^{\mathrm{b}}$ & $0.13^{\mathrm{a}}$ & $0.13^{\mathrm{a}}$ & $0.15^{\mathrm{a}}$ & $0.14^{\mathrm{a}}$ & 0.005 & $<0.001$ \\
\hline Trans-trans C18:2 & $0.07^{\mathrm{a}}$ & $0.06^{\mathrm{ab}}$ & $0.06^{\mathrm{ab}}$ & $0.06^{\mathrm{a}}$ & $0.05^{\mathrm{b}}$ & 0.003 & 0.009 \\
\hline Trans -9 trans -12 + other trans-trans $\mathrm{C} 18: 2$ & 0.23 & 0.26 & 0.25 & 0.27 & 0.24 & 0.020 & 0.268 \\
\hline Cis-9 trans- 12 + other cis-trans $\mathrm{C} 18: 2$ & 0.27 & 0.29 & 0.26 & 0.30 & 0.27 & 0.017 & 0.289 \\
\hline Trans-9 cis-12 C18:2 & 0.04 & 0.05 & 0.04 & 0.04 & 0.04 & 0.004 & 0.700 \\
\hline Trans-11 cis-15 C18:2 & $0.04^{\mathrm{b}}$ & $0.13^{\mathrm{a}}$ & $0.10^{\mathrm{ab}}$ & $0.16^{\mathrm{a}}$ & $0.15^{\mathrm{a}}$ & 0.018 & $<0.001$ \\
\hline Cis-9 cis-12 C18:2 & $2.86^{\mathrm{b}}$ & $2.94^{\mathrm{ab}}$ & $2.76^{\mathrm{b}}$ & $3.40^{\mathrm{a}}$ & $3.04^{\mathrm{ab}}$ & 0.165 & 0.006 \\
\hline $\mathrm{C} 20: 0$ & 0.16 & 0.15 & 0.16 & 0.14 & 0.14 & 0.010 & 0.170 \\
\hline C18:3 & $0.35^{\mathrm{c}}$ & $0.54^{\mathrm{ab}}$ & $0.45^{\mathrm{a}}$ & $0.62^{\mathrm{a}}$ & $0.56^{\mathrm{a}}$ & 0.051 & $<0.001$ \\
\hline Cis-9 trans-11 C18:2 & $0.46^{\mathrm{b}}$ & $0.93^{\mathrm{a}}$ & $0.96^{\mathrm{a}}$ & $1.02^{\mathrm{a}}$ & $1.18^{\mathrm{a}}$ & 0.145 & $<0.001$ \\
\hline
\end{tabular}

${ }^{\mathrm{a}-\mathrm{c}}$ Means within a row with different superscripts differ $(P<0.05)$.

${ }^{1}$ Data correspond to the analysis of milk from 6 individual goats collected at 0 (reference diet) 15, 30, 60, and $90 \mathrm{~d}$.

fat to the goat diets results in no change in milk protein content and may, in fact, lead to an increase (SanzSampelayo et al., 2007).

\section{Fatty Acid Composition of Milk}

Table 3 shows the evolution of the fatty acid profile during the 3-mo monitoring period. A secondary effect due to lactation stage on milk fatty acid could not be excluded in the present study, even if dietary effects are likely to be the major effects. Goats entered the study at about $30 \mathrm{DIM}$, and thus it is possible that some animals were still under negative energy balance, which might have increased the proportion of saturated long-chain fatty acids in milk. The lactation stage effect is marked and mainly linked to lipid store mobilization in early lactation, but it only lasts a few weeks each year (Chilliard et al., 2003).

Lipid supplementation did not substantially influence the concentration of fatty acids from $\mathrm{C} 4: 0$ to $\mathrm{C} 12: 0$, whereas a decline $(P<0.001)$ in the contents of myristic (C14:0) and palmitic (C16:0) acids was observed (Table 3). However, the decreases in C14:0 and C16:0 levels were never greater than $10 \%$ compared with the values 
obtained with the reference diet (Table 3). In agreement, Nudda et al. (2006) did not detect significant changes in the concentration of fatty acids from C6:0 to C12:0 in goat milk fat after supplementation with different amounts of extruded linseed cake. Furthermore, Chilliard et al. (2003) and Chilliard and Ferlay (2004) reported no changes in C4:0 to C8:0 contents after lipid supplementation with several types of basal diets enriched in PUFA. The lack of changes in the content of short-chain fatty acids (C4:0 to C8:0) could be attributed to the fact that they are partly synthesized by metabolic pathways that are independent of acetylCoA carboxylase (Chilliard and Ferlay, 2004).

The stability (C10:0 to C12:0) or the relatively modest decrease (C14:0 to C16:0) observed in the contents of saturated fatty acids could be attributed to the specific characteristics of the metabolism of fatty acids in the goat mammary gland. In contrast to dairy cows, enzymes involved in the pathways of de novo lipogenesis in the goat mammary gland seemed less affected by the lipid supplementation with PUFA. A slight decrease of C8 to C16 in response to feeding lipid supplements was partially attributed to a small variation in acetyl-CoA carboxylase activity and other enzymes involved in de novo synthesis of saturated fatty acids in the mammary gland (Bernard et al., 2005). Additionally the modest decrease in $\mathrm{C} 16$ could also be due, in part, to the lower intake of palm oil with the enriched ration (Table 1).

The incorporation of whole linseed in the diet resulted in significant increases $(P<0.001)$ of $\alpha$-linolenic acid in milk fat (Table 3). Although this increase was far from reaching the proportions documented by Chilliard et al. (2003) when goats received $4 \%$ added fat from either crushed or formaldehyde-treated linseeds, it was similar to the increases reported by Nudda et al. (2006) when supplementing a diet with extruded linseed. In contrast, linoleic acid levels in milk fat did not significantly increase (Table 3 ) when whole linseed and sunflower oil were supplemented despite the fact that diet linoleic acid concentration was $118 \%$ greater in the enriched ration (Table 1). The lack of increase in linoleic acid when supplementing with sunflower oil (rich in linoleic acid) could be partially attributed to fact that the majority of linoleic acid supplied by the supplemented diet was in free form (oil) and thus susceptible to biohydrogenation in the rumen. In any case, previous works compiled by Chilliard et al. (2006) suggest that when rations are supplemented with linoleic acid-rich seeds or oils such as sunflower or soybeans, the linoleic acid proportion in milk fat rarely exceeds that observed with unsupplemented diets by more than $1.5 \%$. Addition of canola oil containing $20 \%$ of linoleic acid up to $6 \%$ in goat diet did not modify the secretion of this fatty acid in goat milk (Mir et al., 1999).

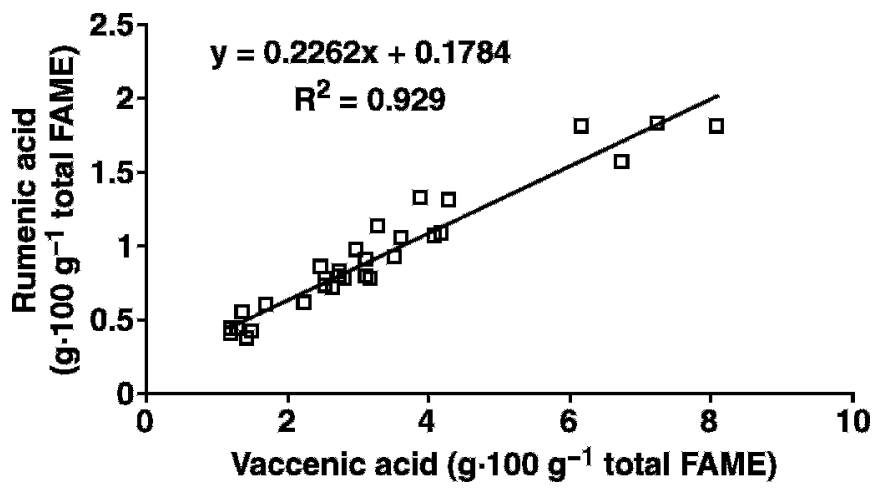

Figure 1. Relationship between rumenic acid (cis-9 trans-11 C18:2) and vaccenic acid (trans-11 C18:1) in goat milk fat from goats fed a reference diet and a diet supplemented with whole linseed $(1.85 \%$ in DM) and sunflower oil $(0.81 \%$ in DM). FAME = fatty acid methyl esters.

Feeding whole linseed and sunflower oil greatly increased $(P<0.001)$ the amount of milk fat trans $\mathrm{C} 18: 1$ isomers (Table 3). Increases in trans C18:1 fatty acids in milk fat is well documented when goats are supplemented with vegetable oils (Chilliard et al., 2003, 2006; Chilliard and Ferlay, 2004). It is also well established that fatty acids with the cis-9, cis-12 isomerism such as linoleic acid, are isomerized to the cis-9, trans-11 conjugated diene before rumen biohydrogenation occurs. Although the predominant biohydrogenation endproduct would be stearic acid, several monounsaturated intermediates are often generated (Palmquist et al., 2005; Sanz-Sampelayo et al., 2007) and thereafter found in the milk. In this study, the most important increase (from 1.38 to $4.05 \%$ of total FAME) was for trans-11 (vaccenic acid, VA). This increase could be attributed to the $\alpha$-linolenic and linoleic intakes, because both fatty acids are precursors of VA in the rumen.

Supplementation was also an effective means of increasing RA in milk fat (from 0.46 to $1.18 \%$ ). Although $\alpha$-linolenic acid is not a direct precursor of RA, feeding whole linseed would result in a large increase in the production of ruminal VA, which can be transported to the mammary gland where it is used for endogenous synthesis of RA by stearoyl-CoA desaturase. Figure 1 shows a strong correlation between RA and VA in the samples of milk fat examined. This correlation is consistent with the predominant origin of this CLA isomer in the goat mammary gland from VA via a desaturase (Chilliard and Ferlay, 2004; Nudda et al., 2006). The ratio of RA:VA in milk fat from goats when fed the lipid supplement (0.25 to 0.29 ) was lower than that from goats when feeding the reference diet $(0.34)$. These results support the idea that the desaturation ratio in 
the mammary gland is decreased by diets that increase the availability of either PUFA or trans fatty acids, as these fatty acids are putative inhibitors of the $\Delta^{9}$ desaturase (Sessler and Ntambi, 1998). Bernard et al. (2005) observed that lipid supplementation led to a decrease in mammary stearoyl-CoA desaturase mRNA and enzyme activity, suggesting negative regulation by dietary PUFA and long-chain fatty acids or, for the unsaturated fatty acids, by their ruminal biohydrogenation products. Chilliard et al. (2006) summarized results from more than 30 different diets and also reported greater values in the ratio RA:VA in unsupplemented diets compared with diets supplemented with lipids.

It should be stressed that the achievement of greater levels of RA in milk fat with oil supplements was accompanied by an enhancement not only of VA, but also of other nonconjugated C18:2 and trans isomers of C18:1 (Table 3). However, maximum concentrations of trans$10 \mathrm{C} 18: 1$ did not exceed $0.70 \%$ and the increase in the VA contents was proportionally greater than the elevation of the levels of the remainder of the trans unsaturated fatty acids. Furthermore, the increase of trans$10 \mathrm{C} 18: 1$ in goat milk fat detected in the present study did not involve a simultaneous reduction in the levels of VA and RA. This fact could be justified considering the basal diet ( $60 \%$ of concentrate in DM) as well as the moderate contents of lipids from sunflower oil and whole linseed (2.8\% in DM) added to the diet. The characteristic shift in the biohydrogenation route toward the formation of trans-10 C18:1 and trans-10, cis-12 C18:2 observed in cows (Palmquist et al., 2005) is related to an altered rumen environment favored by diets with high percentages of concentrate and rich in sources of PUFA. The greatest proportion of each trans fatty acid isomer in milk was obtained in goats fed a highconcentrate diet (Andrade and Schmidely, 2006a; Chilliard et al., 2006). Furthermore, in the present study, secretion of $\mathrm{C} 15$ and $\mathrm{C} 17$ in milk, often resulting from microbial fatty acid metabolism in the rumen (Vlaeminck et al., 2006), was not significantly different between reference and supplemented diets (Table 3), which suggests that the diet assayed (relatively low in concentrate) was efficient in producing sufficient levels of VA without disturbing more rumen metabolism.

Values of RA, VA, and trans-10 C18:1 in milk remained stable during the period monitored in individual goats (Table 3). Previous research in cows fed with a high-fiber diet and different plant oils (Bell et al., 2006) showed that the milk VA and RA responses to lipid supplementation were stable for 9 wk together with moderate trans-10 C18:1 increases. Chilliard and Ferlay (2004) reported that goats would respond better than cows because in goat milk, the RA response was stable for at least 2 or $3 \mathrm{mo}$. With the lipid supplementation levels assayed, our results show that RA was maintained for at least a 3-mo period.

\section{Isomers of CLA}

Table 4 shows the content of the different CLA isomers determined by $\mathrm{Ag}^{+}-\mathrm{HPLC}$. From these data, it can be seen that most of the CLA in goat milk corresponds to RA. Given that the trans-9, cis-11 C18:2 isomer peak is negligible by GC compared with that of cis-9, trans11 C18:2 (data not shown), the contents of the peak 9$11 \mathrm{C} 18: 2$ obtained from $\mathrm{Ag}^{+}$-HPLC analysis should be attributed almost entirely to RA. Thus, at a minimum, $80 \%$ of total CLA in goat milk would be assigned to RA (Table 4). The second most prevalent positional isomer in goat milk fat was 7-9 (cis-trans plus trans-cis) C18:2, representing about 4\% of total CLA. According to previous studies in dairy cows (Yurawecz et al., 1998) and dairy ewes (Luna et al., 2005b), most of that peak had to be assigned to the trans-cis geometrical configuration.

The milk fat contents of $8-10,10-12,11-13$, and $12-$ 14 cis-trans plus trans-cis isomers were clearly lower than $9-11$ and 7-9 in the milks studied (below 3\% of total CLA), whereas the sum of trans-trans was in a range of 3 to $5 \%$ of total CLA (Table 4). Individual transtrans isomers were easily identified by $\mathrm{Ag}^{+}-\mathrm{HPLC}$, and 9-11 was the most abundant. In general terms, these results do not differ substantially from the CLA profile reported for other ruminants (Yurawecz et al., 1998; Luna et al., 2005b).

Most of CLA isomers levels were elevated when the goat's diet was supplemented with vegetable oils (Table 4). The most remarkable increase corresponded to the isomer trans-11, cis-13 C18:2 (Figure 2). Other CLA isomers (trans-12, trans-14 and trans-11,trans-13) also showed sharp enhancements (Figure 2). Few data are reported in the literature on the influence of feeding on goat milk fat CLA profile and, hence, comparisons had to be established with milk from other ruminants. It seems, that dietary supplements high in $\alpha$-linolenic acid may increase the relative proportion of 11-13 and 12-14 positional isomers in dairy cows (Collomb et al., 2004a) and dairy ewes (Luna et al., 2005c). More recently, Sanz-Sampelayo et al. (2007) reported greater amounts of 11-13 isomers (trans-cis and trans-trans) in goat milk fat fed with diet supplemented with linseed. Kraft et al. (2003) hypothesized that the CLA isomers trans-11, cis-13 and trans-11, trans-13 C18:2 are formed in a large quantity as a result of grazing mountain pasture, which is rich in $\alpha$-linolenic acid. The pathway for the hydrogenation of this PUFA in the rumen involves an initial isomerization in which the double bond at the carbon-12 position is transferred to the carbon- 
LUNA ET AL.

Table 4. Effects of dietary supplementation of whole linseed (1.85\% in DM) and sunflower oil $(0.81 \%$ in $\mathrm{DM}$ ) on the conjugated linoleic acid (CLA, $\mathrm{mg} / \mathrm{g}$ of fat) isomer profile of goat milk ${ }^{1}$

\begin{tabular}{|c|c|c|c|c|c|c|c|}
\hline \multirow[b]{3}{*}{ CLA isomer } & \multicolumn{5}{|c|}{ Treatment } & \multirow[b]{3}{*}{$\mathrm{SE}$} & \multirow[b]{3}{*}{$P$-value } \\
\hline & \multirow[b]{2}{*}{ Reference } & \multicolumn{4}{|c|}{ Days of supplemented diet } & & \\
\hline & & 15 & 30 & 60 & 90 & & \\
\hline Trans -12, trans -14 & $0.016^{\mathrm{a}}$ & $0.070^{\mathrm{b}}$ & $0.045^{\mathrm{c}}$ & $0.090^{\mathrm{d}}$ & $0.058^{\mathrm{bc}}$ & 0.0077 & $<0.001$ \\
\hline Trans- 11 , trans- 13 & $0.060^{\mathrm{a}}$ & $0.130^{\mathrm{bc}}$ & $0.111^{\mathrm{b}}$ & $0.140^{\mathrm{c}}$ & $0.110^{\mathrm{b}}$ & 0.0149 & $<0.001$ \\
\hline Trans -10 , trans- 12 & $0.041^{\mathrm{ab}}$ & $0.038^{\mathrm{ab}}$ & $0.043^{\mathrm{ab}}$ & $0.047^{\mathrm{b}}$ & $0.035^{\mathrm{a}}$ & 0.0063 & 0.184 \\
\hline Trans -9, trans- 11 & $0.102^{\mathrm{a}}$ & $0.139^{\mathrm{b}}$ & $0.151^{\mathrm{b}}$ & $0.151^{\mathrm{b}}$ & $0.152^{\mathrm{b}}$ & 0.0103 & 0.006 \\
\hline Trans -8, trans -10 & $0.028^{\mathrm{a}}$ & $0.040^{\mathrm{bd}}$ & $0.031^{\text {ac }}$ & $0.043^{\mathrm{d}}$ & $0.036^{\mathrm{bc}}$ & 0.0035 & $<0.001$ \\
\hline Trans- 7 , trans -9 & $0.025^{\mathrm{a}}$ & $0.047^{\mathrm{b}}$ & $0.037^{\mathrm{c}}$ & $0.049^{\mathrm{b}}$ & $0.045^{\mathrm{bc}}$ & 0.0045 & $<0.001$ \\
\hline$\Sigma$ Trans, trans & $0.272^{\mathrm{a}}$ & $0.464^{\mathrm{bc}}$ & $0.418^{\mathrm{b}}$ & $0.519^{c}$ & $0.436^{\mathrm{b}}$ & 0.0378 & $<0.001$ \\
\hline 12,14 (cis/trans $)^{2}$ & $0.027^{\mathrm{a}}$ & $0.059^{\mathrm{b}}$ & $0.047^{\mathrm{b}}$ & $0.072^{\mathrm{bc}}$ & $0.051^{\text {bd }}$ & 0.0072 & $<0.001$ \\
\hline Trans- 11, cis-13 & $0.029^{\mathrm{a}}$ & $0.122^{\mathrm{b}}$ & $0.134^{\mathrm{b}}$ & $0.166^{\mathrm{bc}}$ & $0.197^{\mathrm{c}}$ & 0.0213 & $<0.001$ \\
\hline $10,12{\text { (cis/trans })^{2}}^{2}$ & $0.037^{\mathrm{a}}$ & $0.043^{\mathrm{a}}$ & $0.042^{\mathrm{a}}$ & $0.053^{\mathrm{bc}}$ & $0.036^{\text {ad }}$ & 0.0047 & 0.021 \\
\hline $9,11(\text { cis/trans })^{2}$ & $4.176^{\mathrm{a}}$ & $8.886^{\mathrm{b}}$ & $8.945^{\mathrm{b}}$ & $9.559^{\mathrm{b}}$ & $11.048^{\mathrm{b}}$ & 1.3208 & 0.002 \\
\hline $8,10(\text { cis/trans })^{2}$ & $0.087^{\mathrm{a}}$ & $0.221^{\mathrm{bc}}$ & $0.176^{\mathrm{b}}$ & $0.235^{\mathrm{c}}$ & $0.233^{\mathrm{bc}}$ & 0.0353 & $<0.001$ \\
\hline 7,9 (cis/trans $)^{2}$ & $0.353^{\mathrm{a}}$ & $0.510^{\mathrm{b}}$ & $0.447^{\mathrm{ab}}$ & $0.523^{\mathrm{b}}$ & $0.536^{\mathrm{b}}$ & 0.0379 & 0.015 \\
\hline$\Sigma$ Cis/trans & $4.710^{\mathrm{a}}$ & $9.841^{\mathrm{b}}$ & $9.790^{\mathrm{b}}$ & $10.607^{\mathrm{b}}$ & $12.101^{\mathrm{b}}$ & 1.3885 & 0.002 \\
\hline Cis-9, cis-11 & $0.107^{\mathrm{a}}$ & $0.122^{\mathrm{ab}}$ & $0.143^{\mathrm{bc}}$ & $0.117^{\mathrm{ab}}$ & $0.158^{\mathrm{c}}$ & 0.0011 & 0.013 \\
\hline
\end{tabular}

${ }^{\mathrm{a}-\mathrm{d}}$ Means within a row with different superscripts differ $(P<0.05)$.

${ }^{1}$ Data correspond to the analysis of milk from 6 individual goats collected at 0 (reference diet) 15, 30, 60, and $90 \mathrm{~d}$.

${ }^{2}$ Cis/trans $=$ cis-trans + trans-cis.

11 position forming cis-9, trans-11, cis-15 C18:3, which is then reduced at both cis bonds to produce VA through trans-11, cis-15 C18:2 as an intermediate. Significant increases $(P<0.001)$ of this $\mathrm{C} 18: 2$ isomer were mea- sured in samples when goats received the lipid supplement (Table 3). Nevertheless, the pathways from trans11, cis-15 C18:2 to trans-11, cis-13 and trans-11, trans13 CLA are still unclear at this stage.



Figure 2. Silver-ion HPLC chromatograms with 3 columns in series and detection at $233 \mathrm{~nm}$ of bulk milk fat from goats fed a reference diet (solid line) and a diet supplemented (dotted line) with whole linseed (1.85\% in DM) and sunflower oil $(0.81 \%$ in DM) for $3 \mathrm{mo}$. AU = arbitrary unit; $c=c i s ; t=$ trans. 
Regarding the minor CLA isomers, amounts of trans10, cis-12 C18:2 in the milk samples studied were very low, less than $1 \%$ of total CLA (Figure 2, Table 4), and values did not change throughout the 3-mo period monitored. This could be explained because in the rumen trans-10, cis-12 C18:2 formed from linoleic acid is converted to trans-10 C18:1. Furthermore, because cis12 desaturase activity has not been detected in the mammary gland or other ruminant tissues, the trans$10 \mathrm{C} 18: 1$ formed in the rumen by biohydrogenation of trans-10, cis-12 C18:2 and absorbed from the intestine would not be transformed endogenously to this CLA isomer. Andrade and Schmidely (2006b) also reported that trans-10, cis-12 C18:2 always remained at trace levels in milk fat from goats, except when this fatty acid was infused postruminally.

\section{CONCLUSIONS}

Feeding both whole linseed and sunflower oil to lactating goats changed fatty acid composition with a slight decrease of the secretion of medium-chain fatty acids and a noticeable increase in the secretion of $\alpha$ linolenic acid, RA, and VA; thereby, giving the lipid fraction a potentially healthier profile. This supplementation was demonstrated to be an effective means of increasing other CLA isomers, mainly 11-13 (transtrans and trans-cis geometric isomers), whereas an increase of trans-7, cis-9 (the second most important CLA isomer from a quantitative point of view) was less remarkable. Additionally, these changes were maintained across lactation. Furthermore, the improvements in the fatty acid profile of milk can be achieved without detrimental effects on animal performance.

\section{ACKNOWLEDGMENTS}

The authors are grateful to the Ministerio de Educación y Ciencia (project AGL2005-04727 CO2-01), the Comunidad Autónoma de Madrid (Madrid, Spain; project S-0505/AGR/000153) and Lodyn (Cindad Real, Spain) for partially financing this project. This study was also possible thanks to the supply of livestock feeding supplements by Lodyn. We thank Jesús Romero at Laboratorio de Lactología y Sanidad Animal (Talavera de la Reina, Castilla-La Mancha, Spain) for conducting the milk composition determinations. Also, we would like to thank M. V. Rodríguez-Pino (Madrid, Spain) for her valuable technical assistance.

\section{REFERENCES}

Andrade, P. V. D., and P. Schmidely. 2006a. Influence of percentage of concentrate in combination with rolled canola seeds on performance, rumen fermentation and milk fatty acid composition in dairy goats. Livest. Sci. 104:77-90.
Andrade, P. V. D., and P. Schmidely. 2006b. Effect of duodenal infusion of trans 10 , cis 12 -CLA on milk performance and milk fatty acid profile in dairy goats fed high or low concentrate diet in combination with canola seed. Reprod. Nutr. Dev. 46:31-48.

AOAC. 1990. Official Methods of Analysis. 15th ed. Assoc. Offic. Anal. Chem., Arlington, VA.

Bell, J. A., J. M. Griinari, and J. J. Kennelly. 2006. Effect of safflower oil, flaxseed oil, monensin, and vitamin $\mathrm{E}$ on concentration of conjugated linoleic acid in bovine milk fat. J. Dairy Sci. 89:733-748.

Bernard, L., J. Rouel, C. Leroux, A. Ferlay, Y. Falconnier, P. Legrand, and Y. Chilliard. 2005. Mammary lipid metabolism and milk fatty acid secretion in alpine goats vegetable lipids. J. Dairy Sci. 88:1478-1489.

Chilliard, Y., A. Ferlay, J. Rouel, and G. Lamberet. 2003. A review of nutritional and physiological factors affecting goat milk lipid synthesis and lipolysis. J. Dairy Sci. 86:1751-1770.

Chilliard, Y., and A. Ferlay. 2004. Dietary lipids and forages interactions on cow and goat milk fatty acid composition and sensory properties. Reprod. Nutr. Dev. 44:467-492.

Chilliard, Y., J. Rouel, A. Ferlay, L. Bernard, P. Gaborit, K. RaynalLjutovac, A. Lauret, and C. Leroux. 2006. Optimising goat's milk and cheese fatty acid composition. Pages 123-145 in Improving the Fat Content of Foods. C. Williams, and J. Buttriss, ed. Woodhead Publishing Ltd., Cambridge, UK.

Collomb, M., R. Sieber, and U. Bütikofer. 2004. CLA isomers in milk fat from cows fed diets with high levels of unsaturated fatty acids. Lipids 39:355-364.

Eulitz, K., M. P. Yurawecz, N. Sehat, J. Fritsche, J. A. G. Roach, M. M. Mossoba, J. K. G. Kramer, R. O. Adlof, and Y. Ku. 1999. Preparation, separation and confirmation of the eight geometrical cis/trans conjugated linoleic acid isomers 8,10- through 11,1318:2. Lipids 34:873-877.

ISO-IDF. 2002. Milk fat-Preparation of fatty acid methyl esters. International Standard ISO 15884-IDF 182:2002. International Organisation for Standardisation (ISO), Geneva, Switzerland.

Kitessa, S. M., S. K. Gulati, J. R. Ashes, E. Fleck, T. W. Scott, and P. D. Nichols. 2001. Utilisation of fish oil in ruminants. II. Transfer of fish oil fatty acids into goat's milk. Anim. Feed Sci. Technol. 89:201-208.

Kraft, J., M. Collomb, P. Möckel, R. Sieber, and G. Jahreis. 2003. Differences in CLA isomer distribution of cows' milk lipids. Lipids 38:657-664.

Lee, K. W., H. J. Lee, H. Y. Cho, and Y. J. Kim. 2005. Role of conjugated linoleic acid in the prevention of cancer. Crit. Rev. Food Sci. Nutr. 45:135-144.

Luna, P., M. Juárez, and M. A. de la Fuente. 2005a. Validation of a rapid milk fat separation method to determine the fatty acid profile by gas chromatography. J. Dairy Sci. 88:3377-3381.

Luna, P., J. Fontecha, M. Juárez, and M. A. de la Fuente. 2005b. Conjugated linoleic acid in ewe milk fat. J. Dairy Res. 72:415-424.

Luna, P., J. Fontecha, M. Juárez, and M. A. de la Fuente. 2005c. Changes in the milk and cheese fat composition of ewes fed commercial supplements containing linseed with special reference to the CLA content and isomer composition. Lipids 40:445-454.

Mir, Z., L. A. Goonewardene, E. Okine, S. Jaegear, and H. D. Scheer. 1999. Effect of feeding canola oil on constituents, conjugated linoleic acid (CLA) and long chain fatty acids in goats milk. Small Rumin. Res. 33:137-143.

Nudda, A., G. Battacone, M. G. Usai, S. Fancelli, and G. Pulina. 2006. Supplementation with extruded linseed cake affects concentrations of conjugated linoleic acid and vaccenic acid in goat milk. J. Dairy Sci. 89:277-282.

Palmquist, D. L., A. L. Lock, K. J. Shingfield, and D. E. Bauman. 2005. Biosynthesis of conjugated linoleic acid in ruminants and humans. Adv. Food Nutr. Res. 50:179-217.

Sanz-Sampelayo, M. R., J. J. Martín-Alonso, L. Pérez, F. Gil-Extremera, and J. Boza. 2004. Dietary supplements for lactating goats by polyunsaturated fatty acid-rich protected fat. Effects after supplement withdrawal. J. Dairy Sci. 87:1796-1802. 
Sanz-Sampelayo, M. R., Y. Chilliard, Ph. Schmidely, and J. Boza. 2007. Influence of type of diet on the fat constituents of goat and sheep milk. Small Rumin. Res. 68:42-63.

Sessler, A. M., and J. M. Ntambi. 1998. Polyunsaturated fatty acid regulation of gene expression. J. Nutr. 128:923-926.

Vlaeminck, B., V. Fievez, A. R. J. Cabrita, A. J. M. Fonseca, and R. J. Dewhurst. 2006. Factors affecting odd- and branched-chain fatty acids in milk: A review. Anim. Feed Sci. Technol. 131:389-417.

Yurawecz, M. P., J. A. G. Roach, N. Sehat, M. M. Mossoba, J. K. G. Kramer, J. Fritsche, H. Steinhart, and Y. Ku. 1998. A new conjugated linoleic acid isomer, 7 trans, 9 cis-octadecadienoic acid, in cow milk, cheese, beef and human milk and adipose tissue. Lipids 33:803-809. 